\title{
What Do Public Sociologists Do? A CRitique of Burawoy ${ }^{1}$
}

\author{
Avi GolDBERG \\ AXEL VAN DEN BERG
}

Abstract. In response to Michael Burawoy's call for a "public sociology" and to the question of public sociology's place vis-à-vis Canadian sociology, this essay presents four major points. First, Burawoy's conception of public sociology is a hybrid of several different kinds of activities and stances which should be assessed separately on their respective merits. Second, many of his recommendations for more public activity on behalf of or by sociologists, including better marketing of the discipline, sociologists taking on various civic roles, and sociologists acting as public intellectuals, are entirely uncontroversial and/or actively and widely put into practice in Canadian sociology already. Third, two of his recommendations, the promotion of "organic" public sociology and the conversion of the discipline of sociology into a political public acting in defense of civil society, are potentially much less innocuous. They would not bring the benefits expected by Burawoy and, depending on how they were implemented, they could be self-destructive as well as politically and morally dubious. Fourth, our brief survey of some trends in Canadian social movements scholarship suggests that, first, there is no "hegemony" of "professional" sociology in Canada's universities and, second, that, promoting more public-oriented sociology in this subfield poses risks to the credibility and potential applied efficacy of Canadian scholarship and would be politically and morally dubious to boot.

Keywords: public sociology, organic intellectuals, social movements, Canadian sociology

1. We dedicate this article to our good friend and colleague Jeff Cormier. Jeff had an unrivalled ability to take opposite sides in any debate, and to do so in a way that invariably gave us all a serious run for our money, whatever side we happened to be on. This consummate skill of his had nothing to do with any lack of commitment on his part, however. Rather it was testimony to his deep commitment to the idea that one can only expect to persuade the unpersuaded if one is seen to have taken all sides to a dispute equally seriously. And he thought, as do we, that this is the essence of good sociology and science more generally. He was convinced that sociology could be a force for the good precisely because/when it is able to persuade all publics engaged in their various conflicts that its findings and conclusions rest on fair, honest, and reliable methods and assessments and that they are consequently valid for them as much as for all others. This is the position we try to defend in this article and we hope we have done Jeff's memory some justice with it. We miss him. 
Résumé. En réaction à l'appel de Michael Burawoy pour une «sociologie publique » et à la question de la situation d'une telle sociologie par rapport à la sociologie canadienne, ce texte propose quatre points majeurs. En premier, la conception de Burawoy d'une « sociologie publique » consiste en réalité d'un mélange de plusieurs activités et positions dont chacun devrait être évalué pour ses propres mérites. Deuxième point, plusierurs de ses recommandations d'activités publiques par des sociologues et/ou en faveur de leur discipline, y inclus un meilleur marketing de la discipline, de l'activisme civique dans les organes et organisations et des interventions dans les débats publics par des sociologues comme "intellectuels publiques », ne sont aucunement controversées et font déjà partie de la pratique acceptée dans la sociologie canadienne. Par contre, et ceci représente notre troisième point, deux de ses recommandations, soit la promotion d'une sociologie publique « organique » et la conversion de la discipline dans un public politique à la défense de la « société civile », pourraient être considérablement moins innocentes. Sans aucun doute ces dernières ne porteront jamais les fruits auxquels Burawoy s'attend pour la discipline et, dépendant de la manière dans laquelle elles seraient mises en oeuvre, elles pourraient se montrer extrêmement auto-destructives ainsi que moralement et politiquement douteuses. Finalement, notre bref tour d'horizon de certaines tendances dans la sociologie canadienne des mouvements sociaux nous montre que, premièrement, il n'existe aucun signe d'une « hégémonie » de la sociologie «professionnelle » dans les universités du Canada et, deuxièmement, que la promotion d'encore plus de sociologie orientée vers les «publiques » spécifiques nuirait à la crédibilité et l'efficacité appliquée de la recherche sociologique canadienne ainsi que d'être d'une douteuse valeur morale et politique.

Mots clés: sociologie publique; intellectuels organiques; mouvements sociaux canadiens; sociologie canadien

\section{INTRODUCTION}

M ichael Burawoy certainly seems to have the requisite organizational and marketing savvy to be a successful "public sociologist." Preaching from a few well-chosen pulpits, the ASA Presidency first among them, he has almost singlehandedly created a multinational cottage industry busily debating his ideas about the future of our discipline. ${ }^{2}$ The responses have been as varied as they have been numerous. While many have been quite critical, the criticisms have originated from a bewildering range of often entirely opposite positions on the ideological-

2. A casual search on the EBSCO Socindex data base turns up close to 160 entries under "public sociology" starting in 2003, with contributions from and/or about sociologists in South Africa, Britain, Germany, Ireland, Slovenia, China, France, India, the former Soviet republics, translations of Burawoy's initial speech into Spanish and German, and at least 7 major journals that devoted special symposia and debate sections to Burawoy's proposals. 
philosophical spectrum, as well as from every imaginable position in between. Burawoy himself takes this multiplicity of positions as evidence for the plausibility of his own ideas about different kinds of sociology and the possibility of a fruitful, collaborative division of labour among them (Burawoy 2007:246). We suspect it is more likely an expression of the depth and the breadth of our discord concerning the basic question of what we want with our discipline. ${ }^{3}$

The variety of responses is also due in part to key ambiguities and a certain murkiness in Burawoy's own thinking. As some critics have noted, in his desire to offer something to everyone he exhibits a politician's zeal for papering over the tensions and possible contradictions in his own arguments, which has produced a considerable amount of confusion about what exactly he is arguing for (see, e.g., Hays 2007:80, 83). Much of his elaborate taxonomizing of different types of sociology and knowledge serves primarily, it seems to us, to give the comfortable feeling that there is room around the table for all of our different ways of doing sociology and to lend his general argument an aura of a "let 100 flowers bloom" tolerance. Yet the effect seems to have been the opposite: defenders of "professional" and policy sociology see Burawoy's appeal as a thinly disguised attempt to push the discipline towards an ultimately self-destructive politicization (Brint 2007; Massey 2007; Nielsen 2004; Smith-Lovin 2007; Tittle 2004), while those of a more "critical" bent insist, with an iron binary logic reminiscent of old Leninism (see van den Berg 2003a:109-141), that sociology is either on the side of the downtrodden or a witting or unwitting handmaiden of the powers that oppress them (Collins 2007; Hays 2007; Piven 2007). As Davies shows with respect to the Canadian scene in his contribution to this special issue, these two sides are as convinced of the obvious superiority of their own approaches as they are unlikely to be drawn into a constructive dialogue, let alone any amicable division of labour, by soothing talk like Burawoy's (cf. Brint 2007:252-254).

But then, Burawoy is not really interested in these particular "faces" of sociology, giving them little more than lip service. His central point is that we should collectively engage in, encourage, and reward the fourth type, public sociology, more and treat it as at least equal in importance to the other three. We should manifest ourselves more emphatically as sociologists in the public arena and be more appreciative of those who

3. Burawoy's taxonomy of four types of sociology, each with its own characteristic kind of knowledge, does indeed bear an "uncanny resemblance" to Parsons' work (Burawoy 2005:11, fn.5), not least in its comprehensive intent and utterly imprecise concepts, as a result of which one could hardly fail to fit all responses imaginable into one or another of its pigeon-holes. This hardly constitutes confirmation of the argument that the four types describe the discipline adequately or usefully. 
do and reward them accordingly. The collective benefit of this greater presence in the public arena, he claims, would be a sociology more visibly relevant to public concerns, a higher status among the public for the discipline as a whole, and finally a more effective "defense of humanity" (Burawoy 2005:25) against the twin evils of "state despotism" and "market tyranny" (2005:24; see also Burawoy 2004:1615-1616).

Given the centrality of the notion of public sociology to his entire argument Burawoy is actually remarkably unclear, evasive, and even contradictory on his exact meaning of that term, as many commentators have noted (see, e.g., Brady 2004; Hays 2007; Tittle 2004). For Burawoy, public sociology seems to include everything from more effective marketing of the discipline's accomplishments, to more active participation in public debates through the media; greater civic participation at various levels of governance; forming close alliances with the whole range of interest groups, movements, and causes in the public realm; creating such publics; and, finally, turning the whole discipline into "a public that acts in the political arena" (Burawoy 2005:8). This proliferation of different senses in which he uses the central term in his argument is no doubt the product of his essentially political, rather than analytical, purpose: it offers something to everyone. Obviously, it is one thing to recommend that our major association put out a more accessible glossy magazine to promote the discipline among a wider public but quite another to call for the discipline to take a public stand on, say, the war in Iraq. ${ }^{4}$

In this comment we first identify and consider five different senses in which Burawoy uses the term "public sociology" in order to assess whether a case can be made that it has been undervalued in the profession in Canada and whether doing more of it and/or appreciating it more is likely to produce any of the promised collective benefits for either the discipline or for the defense of humanity. To illustrate our doubts regarding both the potential relevance and implications of embracing Burawoy's call for "public sociology" we next evaluate it in light of noteworthy trends in the sociology of collective action in Canada.

\section{“Public Sociology" as Better Marketing}

This is one way in which Burawoy suggests we can and should do more "public sociology" as he praises the American Sociological Association's "vigorous efforts in outreach and lobbying" (Burawoy 2005:25). The idea is that we should do more to spruce up our public image by

4. The ASA did this in 2003, after forceful lobbying by Burawoy and others (see, e.g., Burawoy 2004:1603-1618). 
putting out newsletters, press releases, public events, lobbying policymakers, etc. to celebrate and call attention to the accomplishments of the discipline and their practical importance to matters of public concern.

If this is all Burawoy has in mind, then the argument is utterly uncontroversial and has been made many times before. ${ }^{5}$ As he points out himself, the ASA is already doing this and in Canada, at least since Marc Renaud's presidency, better marketing and lobbying for the social sciences more generally has been a major goal of the SSHRCC. Assuming that at least part of the discipline's relatively low status is a matter of bad optics (though how much is due to this probably is quite debatable; cf. Halliday and Janowitz 1992; Wilson 2007), the likely outcome of such efforts is not terribly contentious. Nor, finally, do we expect much controversy about appreciating and rewarding those in marketing and lobbying jobs. Presumably one would wish to pay them a decent salary as consultants or officers of the discipline's organizations and associations, celebrate their greatest accomplishments by honourable mentions in various newsletters and with modest prizes perhaps, but not award them tenure at a major university.

\section{"Public Sociology" as more "Relevant" Sociology}

Like so many before him, Burawoy also calls for sociology to address the issues and concerns that really matter to people out there in the real world rather than "regress toward insularity ... focusing on the seemingly irrelevant," producing either "incomprehensible grandiosity or narrow 'methodism"” (Burawoy 2005:17) as professional sociology, in its more pathological moments, is wont to do. But, as several commentators have noted (Hays 2007; Tittle 2004; Wilson 2007), in a trivial sense all of sociology is to some degree relevant to social life and thus to the "public." So why and how does this inherent "publicness" require more emphasis and credit? Are we to give more credit to the work of sociologists who are self-consciously motivated by a desire to serve some "public" cause than to that of those who claim they are just trying to figure out how a particular social phenomenon works? Isn't that like favouring the work of the cancer researchers who are motivated by the ideal of reducing human suffering over those who are plainly interested in the intricacies of carcinogenesis? We can admire the moral commitment of the former, of course, but we would be very foolish indeed to treat the latter's findings as any less valid because of their morally less high-minded origins.

5. For instance in Herbert Gans' 1988 presidential address to the ASA (Gans 1989). 
Are we to push for a sociology that more directly addresses the current concerns of the various social "publics" out there? The underlying assumption here seems to be that existing institutional mechanisms favour research that is "insular" and irrelevant to such publics. But is this a reasonable assumption? If anything, one could make the opposite case about current trends in research funding. The most notable recent trend in the funding policies of major granting agencies, including that of our own SSHRCC, has been a remarkably energetic push towards greater "relevance." In exchange for their scarce research dollars, such agencies now routinely demand ever more elaborate justifications in terms of "societal benefits" and ever more detailed "dissemination strategies" to reach a plethora of purported "next users" of the research findings, and they strongly encourage researchers to involve and collaborate with organizations and institutions that represent "civil society." ${ }^{\text {In }}$ effect, these agencies are imitating the long-established practice in the natural and medical sciences of encouraging researchers to focus on issues and problems that are thought to have important applications in the near or distant future. To put it differently, these funding-backed pressures operate to keep our research "relevant," providing those of us who might otherwise be motivated merely by idle curiosity with a strong incentive to steer that curiosity into "socially useful" directions.

Whether this is a good or a bad thing is not obvious, however. For one thing, one can legitimately ask who should be the judge of societal "relevance"; it is not immediately clear which sociologists, or which body of sociologists, would have a better claim to this than the SSHRCC's governing council. For another, "current concerns" in the social world tend to be remarkably volatile and fad-prone with the result that increasing amounts of time and energy are being wasted on opportunistic grantsmanship, the (re-)tailoring of research grant applications to fit the latest enthusiasms, and the writing up of platitudes about societal benefits and dissemination strategies, as many of us are all too painfully aware. Thus current trends would seem to strongly discourage the kind of basic research and careful methodological work of "professional" sociologists that Burawoy so cavalierly dismisses as "insular." In the long run, this may seriously undermine basic research in Canada in favour of superficial, apparently policy-relevant work based on grantsmanship.

6. As these lines were written the European Commission's Research Information Service announced a new program called Platon+ specifically for the social sciences and humanities. Platon+ "will develop activities to disseminate SSH research results to four major stakeholder groups: researchers, businesses including small and medium enterprises (SMEs), policy decision-makers, and civil society organisations (CSOs)" (http:// cordis.europa.eu/search/index.cfm?fuseaction=news.document\&N RCN=29471). 


\section{Public Sociologists as Public Intellectuals}

Then again, merely doing work that promises to deliver "social benefits" of one kind or another does not really measure up to Burawoy's grander Millsian vision. According to this vision, the "public sociologist" is an "engaged" sociologist, taking stances on behalf of various public causes as polemicist, activist, or participant in public debates. This is a slightly more complicated matter depending on the exact meaning of taking "public stances." There appear to be several possibilities.

The most obvious one, and one Burawoy seems to have in mind when he talks about public sociologists participating in public debates, questioning goals and values rather than means, engaging in public dialogue, etc., is the public sociologist as public intellectual, one who actively intervenes in the public debates of the day through books, articles, editorials, and speeches that address a larger general audience beyond the confines of the discipline and academia. Names like Daniel Patrick Moynihan, Daniel Bell, Nathan Glazer, Dennis Wrong, Amitai Etzioni and Robert Bellah come to mind. But this fairly random list immediately makes nonsense of a central part of Burawoy's argument: not even in the United States have "public sociologists" ever had to play second fiddle to their supposedly more "professional" brethren, much less being "subjugated" to them (Burawoy 2007:250). The US has, in fact, quite a long and lively tradition of public sociologists as part of a wider tradition of public intellectuals, thank you very much. They may not quite have the same celebrity status as the Great Gurus of Paris' Left Bank are reputed to enjoy - a celebrity which, we suspect, is much envied by some of their Anglo-Saxon colleagues - but the tradition is not any less impressive for all that. ${ }^{7}$

It is not so much a tradition of public sociologists as it is one of public intellectuals, some of whom happen to be professional sociologists but many of whom are not, including the likes of John Kenneth Galbraith, John Rawls, Edward Said, Noam Chomsky, Michael Walzer, Robert Putnam, and Irving Howe, to name but a few. This suggests several serious problems with respect to Burawoy's argument, it seems to us. First, given that a thriving tradition of public intellectuals, many of whom are sociologists by occupation or credentials, already exists why call for more of this kind of "public sociology"? How much more do we need, and what would be the benefits of such an increase? While occasionally tipping his hat at some of these public intellectuals (Burawoy 2005:7-9), Burawoy offers no answers to these obvious questions.

7. Such "Dreyfus envy" is no doubt quite widespread in the Anglo-Saxon world and beyond (see Collini 2006). 
More to the point, one has to wonder why and how sociologists in particular should be called upon to conduct themselves more like such public intellectuals. Should we insist that, say, Amitai Etzioni or Daniel Bell identify themselves more emphatically as sociology professors when they engage in public debate? What good would that do, and to whom? It seems at least possible that this might actually end up weakening both their influence in the public arena and that of the discipline of sociology as whole!

Burawoy claims that we sociologists have a special mandate to fulfill among public intellectuals: we are destined to be the defenders of an embattled "civil society" or even "humanity," in contrast to economists and political scientists who naturally identify with "the market" and "the state" respectively (Burawoy 2005:24-25). Just a glance at the more or less random lists of public intellectuals and sociologists that we rattled off above should suffice, it seems to us, to expose the utter silliness of this claim. Are we really going to argue that Amitai Etzioni and Daniel Bell are the defenders of "humanity" while Paul Krugman and Robert Putnam are not, simply by virtue of the former's professional sociological credentials? Quite apart from the fact that, if anything, many sociologists have tended to advocate state intervention while many political scientists have denounced it, ${ }^{8}$ proclaiming ourselves the defenders of "humanity" seems likely to make our discipline a laughing stock both within and outside academia.

Third, as our lists also suggest, neither public sociologists nor public intellectuals are a particularly homogeneous lot, ideologically speaking. In fact, they are literally all over the political map. While Burawoy occasionally recognizes this in passing (Burawoy 2005:8-9), he does not seem to grasp its general import for his argument. If, as appears to be the case, public sociologists of this variety basically represent the entire political spectrum, what effect can we expect their public activities to have on the public perception of the discipline? At most, it seems to us, they would confirm the public's general impression that sociologists are

8. It sounds vaguely plausible to argue that economics has an "interest" in the "expansion" of markets, as Burawoy (2005:24) does, but that "political science depends on the state with an interest in political stability"? This description hardly fits the rather prominent chunk of political science known as Public Choice theory. And what are we to make of the numerous sociological advocates of greater state intervention to counteract the alleged inequities of the market, particularly, but by no means only, in the sociology of the welfare state and social stratification (e.g., Evans et al. 1985; Esping-Andersen 1985; 2002; Korpi 1983; Stephens 1980)? Are they all "really" political scientists? If anything, it could be argued that while political scientists have been arguing for a reduction in the size of the state in favour of an idealized textbook version of the perfectly competitive market, sociologists have been arguing for greater state intervention in the market by an equally idealized "democratic" state (see van den Berg 2003a; 2004). 
as divided as the public is on the issues at hand. This may not be a bad thing - far from it - but it is unlikely to strengthen the discipline's public image or authority as envisaged by Burawoy.

Finally, Burawoy seems convinced that the culture of public intellectuals/sociologists is uniquely weak in the US. In view of what we have just said, this is not exactly obvious. If anything, one gets the impression that it is actually weaker in Canada, in spite of the prominence of people like John Ralston Saul, Michael Ignatieff, Mordecai Richler, and, of course, Charles Taylor and Gérard Bouchard. But then, maybe this is merely a manifestation of the universal sense outside of France that "we" don't have, or have lost our culture of, public intellectuals, as Collini suggests (Collini 2006).

\section{“Organic” Public Sociology}

The likes of Bell, Glazer, and so on are merely "traditional public sociologists" according to Burawoy $(2005 ; 2007: 253)$. They cater to relatively "thin" and often privileged publics from a distance. The ones that Burawoy really admires are the "organic" or "grassroots" public sociologists who carry "sociology into the trenches of civil society" (Burawoy 2004:104) as they circumvent

the media in favor of a direct unmediated relation to publics, which might include neighborhood associations, communities of faith, labor movements, environmental groups, in other words, publics that are local, thick (with intensive interaction among their members), active, and often counterpublics that make demands on municipalities or state governments. (Burawoy 2007:254; 2004:104, 128; 2005:7-8)

These are the true wellsprings of resistance on behalf of "humanity" against the "state and economy [as they] collude in the cooptation, regulation, surveillance, and repression of society" (Burawoy 2007:256).

One might ask, how does this differ, really, from asking sociologists to take their civic duties more seriously as citizens? Few "professional"

9. The entirely unreflective romanticization of a friendly, cosy, consensual "civil society" as opposed to the nasty, cold and oppressive "state" and "market" in Burawoy's argument has been noted by others (see, e.g., Brady 2004:1633-1634; Brint 2007:245-246). It bears more than a passing resemblance to Habermas's no less unreflective romanticization of the "communicative rationality" characterizing a "lifeworld" in danger of being "colonized" by the big, bad "systems" of state and economy, driven by power and money (van den Berg 1990). While Burawoy occasionally concedes that civil society may not be exactly a model of democratic tolerance and humanity (Burawoy 2005:2425; Burawoy et al. 2004:129) he once again does not appear to grasp in the slightest how fundamentally this undermines his whole claim that sociology is somehow destined to become the great defender of "humanity" (see also Brint 2007:246-248). 
sociologists would object to this, although they might ask why sociologists should be singled out in particular for such high civic virtue. In fact, to argue that sociologists, qua sociologists, should participate more actively in public life than any other category of citizens smacks of an oddly elitist mindset for one so concerned to promote democracy and equality (cf., e.g., Tittle 2004). Moreover, it is not exactly clear how the discipline as a whole would benefit in one way or another from more sociology professors rather, than, say, nurses, plumbers, or lawyers, facing each other at opposite sides of city councils, zoning disputes, pro- and antiIsrael demonstrations, and so on, let alone how this would materially affect the "defense of mankind." The disproportionate number of lawyers active in US politics certainly does not appear to have improved their collective occupational or disciplinary respectability!

Surely there is some sociological expertise that could be of use to various groups and organizations operating in "civil society"? Conversely, surely attempts to put that expertise to practical use, and the outcomes of those attempts, constitute a potentially quite valuable source of quasi-experimental evidence for "professional" and "policy" sociology. This is what many of the contributors to the Boston College symposium organized in response to Burawoy's call for more public sociology have argued (Burawoy et al. 2004). Several of them consider themselves to be "organic" public sociologists in Burawoy's sense, and they are happy to describe the ups and downs of offering their particular expertise to a variety of community groups struggling to be heard in the political arena as well as the many lessons they have learnt from interacting with publics in the "real" world out there.

Again, few, if any, "professional" sociologists would feel the need to object to any of this in principle but they would not call it "organic public sociology." They would call it "applied sociology," and, on the whole, be quite happy to recognize the potential two-way benefits that can flow from the natural experiments that such applied sociologists help conduct. Moreover, they would argue that ideally such applied sociology should be tested in a wide range of social settings and on the full range of groups and interests that populate "civil society." Burawoy appears to concur with this last point, insisting repeatedly that public sociology does not have any particular political colour.

Public sociology has no intrinsic normative valence, other than the commitment to dialogue around issues raised in and by sociology. It can as well support Christian Fundamentalism as it can Liberation Sociology or Communitarianism. (Burawoy 2005) 
If we are to take this seriously, we have to ask again what the difference is between Burawoy's "organic" public sociology and plain applied sociology. If we are really talking about plain old applied sociology, this raises two further obvious questions. First, why is it so terribly important that "professional" sociology, or the university, pay greater tribute to this kind of applied sociology? Maybe a case can be made for teaching more courses in applied sociology, with appropriate case studies and group projects, much as they do in management courses. This might, for instance, give some of our students a better idea of what they can do with their sociological qualifications other than pursuing an academic career. Perhaps through greater and more systematic attention to the lessons to be learnt from such natural experiments in applied sociology professional sociology could be considerably enriched. This is, presumably, what happens in disciplines such as management, nursing, and social work, the latter of which, from this perspective, could be seen as a kind of applied sociology avant la lettre. All of these disciplines rely heavily on their academic branches being informed by what works "in the field," as do other profession-based disciplines like engineering, law, and medicine. ${ }^{10}$

In these disciplines, the practitioners, the professionals in the more common sense of the term, ${ }^{11}$ reap their principal status and rewards, modest though they may be for some of them, outside academia and quite independently from it. Why do Burawoy and his organic public sociologists insist on the need for public sociology to gain greater status and rewards within the university and academia (see also Stacey 2007)? Why are the appreciation, satisfaction, and possible material support from their respective publics in the "real" world not enough to satisfy their needs for status and reward? This question points to a rather surprising tacit assumption of Burawoy's: what really appears to matter to him is what the academic world thinks. When he presents sociology as a Bourdieuian "field of domination," Burawoy is effectively talking about the academic field only. While among academically employed sociologists "professional" sociology may enjoy the highest prestige, we have no reason to believe that in the eyes of the wider public, much less of those publics that have had the pleasure of having academic sociologists come to their aid, it is viewed as more prestigious than the grass-roots

10. Putney et al. (2007) make a similar point with respect to gerontology.

11. Burawoy's use of the term "professional" for what others would call academic or "(social-) scientific" sociology, with all the associations attaching to the former of monopolizing practical knowledge and credentialing authority in order to raise the professionals' income and status, only adds to the many confusions he has introduced into the debate, as can be seen rather clearly for instance, from Charles Derber's comments in Burawoy et al. (2004:119-121). 
applied variety Burawoy advocates. In fact, from some of the anecdotal evidence presented by the aforementioned practicing public sociologists one might get the opposite impression: those publics tend to be rather more skeptical of the utility of the abstract, vague, impractical, and unintelligible utterances of "professional" sociologists than of the practical advice of the effective street-level "organic" sociologist, and for good reason! $!^{12}$ So why this hankering after respectability within academia itself? Why is it so important for the university to hire and support sociologists engaged in such applied practice in addition to its traditional mandate of conducting fundamental research and teaching?

In other words, as in the case in the other disciplines mentioned, there is nothing wrong with the fact that applied sociology is valued for the effectiveness of the services it can render to its customers/beneficiaries and that it is valued and rewarded for this by those customers/ beneficiaries. No doubt the effectiveness of those services will depend to some considerable degree on the quality of the social-scientific ("professional") sociology it attempts to put into practice. Nor is there any doubt that valuable lessons are to be learnt from these applications for socialscientific sociology. For that matter, the same goes for the successes and failures of "policy sociology," which is also a type of applied sociology. In fact, the only difference between Burawoy's "organic" sociologists and his "policy" sociologists is that the former share their customers' goals and ideals while the latter do not. This difference, in turn, explains why the latter need to be paid for their services while the former will often provide them pro deo, that is, for the sheer satisfaction of serving a cause they support. This situation is, it seems to us, just as it should be. In fact, one can even make the stronger case that only the customers/beneficiaries should be the judges of the value of the work of such applied sociologists and not their academic peers. If obtaining tenure or promotion in academia were as important as satisfying their customers/beneficiaries to applied sociologists, this could only serve to distract them from doing the latter as effectively as possible. Thus, we see no need for any revaluation of either form of applied sociology, within or outside the academy.

So is there, then, no real difference between Burawoy's "organic" public sociology and the traditional, and wholly uncontroversial notion of applied sociology? If we can believe that Burawoy really means what he says when he insists that such a sociology has "no intrinsic normative valence" then the answer would have to be "yes" and one would have to wonder what the fuss was all about. On closer inspection this is probably not exactly what Burawoy has in mind. Sociology, he tells us, is natu-

12. See, e.g., Charlotte Ryan's remarks in Burawoy et al. (2004:111-112). 
rally aligned "with humanity's interest in opposing the erosion of civil liberties, the violation of human rights, the degradation of the environment, the impoverishment of working classes, the spread of disease, the exclusion of ever greater numbers from the means of their existence, and deepening inequalities"(Burawoy et al. 2004:125), it is naturally inclined towards combating "the inequalities and injustices we [sociologists] study and inveigh against" (2004:129). Broad as these concerns may seem, one somehow gets the feeling that they do not encompass the entire conventional political spectrum. In fact, the "normative valence" among the self-proclaimed "organic sociologists" who have responded favourably to Burawoy's call is decidedly and unanimously on the political left, with not a trace of any "Christian fundamentalism" or even "communitarianism" to be found. In short, Burawoy and his supporters are really only talking about "organic public sociologists" of the political left, as is plainly and unapologetically on display in the contributions to the Boston College symposium (see also Bonacich 2007).

We would like to raise at least two basic questions about this kind of exclusively left-wing "organic public sociology." First, one may wonder whether the picture of a repressed, underrewarded, and underappreciated minority of practitioners of this kind of sociology within academia is really accurate. Below we will address this question for Canadian social movements sociology where we suggest that this picture grossly misrepresents the reality of that particular field.${ }^{13}$ Second, one has to wonder how much the discipline as a whole is likely to gain from the activities and prominence of its exclusively left-wing "organic" activists within their respective left-wing groups and causes. Can we really expect these to enhance our standing among the public at large, let alone among those active in mainstream or even moderately "alternative" organizations and institutions?

But then, we may not want to please the mainstream or what used to be called "the establishment." Maybe we want to create entirely new "publics" to combat and eventually replace that very mainstream (e.g., Burawoy et al. 2004:128-129). All the somewhat disingenuous disavowals of any "intrinsic normative valence" notwithstanding, this is quite evidently what Burawoy and his supporters ultimately have in mind. The causes they favour, they believe, are in some objective sense not only the causes of Justice but also those of the great "masses" of the world population ("humanity," no less) and of the ultimate, "progressive" direction of History itself. Marxism wasn't dead; it was just resting....

13. We suspect our conclusions would hold for other areas and for other countries as well, including the US. 


\section{The Discipline as a Political Public}

This brings us to the fifth and most ominous interpretation of the notion of a more "public sociology," hinted at by Burawoy when he calls on us to "constitute ourselves as a public that acts in the political arena" (2004:8). Referring to the ASA, as the new president, he asserts that

[t]he association is a political venue unto itself - a place to debate the stances we might adopt.... Recognizing we are part of the world we study, we must take some stance with respect to that world. To fail to do so is to take a stance by default. (Burawoy 2004:1606)

In this interpretation, sociology should take political stances as a discipline. Such positions are to be arrived at, to be sure, "through open dialogue, through free and equal participation of our membership, through deepening our internal democracy" (2004:1606).

For Burawoy, the desirability of this taking of political sides by the discipline as a whole is intimately connected with what he sees as our right and obligation to go beyond merely providing "instrumental" knowledge to our clients and publics, engaging with them in a dialogue about the ultimate values and goals that animate our research and our social lives (Burawoy 2005:9).

Thus, empirical science can only take us so far: it can help us understand the consequences of our value commitments and inform our value discussions, but it cannot determine those values. Determining values should take place through democratic and collective deliberation. (Burawoy 2004:1606-1607)

To assess what may be at stake here, it will help to consider the possible outcomes of a process of "open dialogue" among ourselves to determine "our" values and political stances. The most likely outcome, no matter how "deep" our internal democracy, is, pace Habermas, a fairly wide range of values and opinions no doubt located somewhat to the left of that of the rest of the population. This will hardly surprise those few among that rest of the population who pay any attention at all to what we sociologists think. It simply confirms the rather well-known fact that sociologists tend, on average, to be somewhat left of centre in their values and politics, but no less divided than the general public for all that (Cohen 2008; Gross and Simmons 2007).

Should we perhaps advertise this state of affairs more loudly to the general public? What exactly could we or, for that matter, those leftof-centre causes some of us hold dearer than the average citizen does, hope to gain from this? It certainly will not do anything to strengthen the 
credibility of our research results in the eyes of that large majority of the population who do not necessarily share "our" values and politics. And does anyone really think that, given the many divisions about values and politics among ourselves, the fact that on average we tend to lean slightly further to the left than the proverbial person in the street is really going to strengthen the fight against the many "inequalities and injustices" Burawoy mentions? As Burawoy himself notes somewhat wistfully, sociologists' concerns are "simply too far to the left" (Burawoy et al. 2004:127) to be as influential in policymaking circles as, say, economists are (cf. Turner 2007:265).

Suppose, for the sake of argument, that our fundamental values are close enough and/or that we as a profession are so much better at conducting "open dialogue" through "democratic and collective deliberation" than ordinary folks that, by some Habermasian miracle, we were able to come to something like a consensus of a sizable majority regarding nontrivial issues of values and politics. Having reached such a consensus, suppose we then went out and advertised this particular consensus as the political position of the discipline. ${ }^{14}$ What exactly would that mean and what good would that do us or the rest of the world?

First, there is the awkward problem of dissident minorities. Declaring the majority position, no matter how large that majority, to be the position of the entire discipline smacks more of Leninist "democratic centralism" than of any "deepening of our internal democracy": the minority positions are simply silenced. Even then, if all we do is declare the position adopted by the majority of our members to be the discipline's we still do nothing more than advertise our slightly left-of-centre leanings as discussed above.

We could also present the values and politics of the majority among us, particularly if it were a near-unanimous majority, as not so much a matter of what our values and politics happen to be but rather as a manifestation of our special sociological expertise. In other words, we could claim that, by virtue of the near-unanimous agreement among ourselves about these particular values or political stances they represent sociologically "valid" positions and values. It helps that fashionable contemporary theory is all about blurring the distinction between scientific methods of validation and other ways of finding consensus. Such

14. We leave aside here the question of the rather less appealing way in which these things are usually done in reality. Whenever some professional association takes a political stance like the one on the war in Iraq, or the need to "Canadianize" Canadian universities (see Cormier 2004), or the boycott of Israeli academics (see below) by virtue of some "majority" vote among members or plenary session attendants, there is invariably a strong suspicion of a not-so-democratic militant minority holding the association as a whole hostage with questionable voting and agenda-setting tactics. 
theoretical sophistication can be conveniently invoked to dismiss any awkward, naively positivist questions about what exactly we mean by "sociologically valid." This is exactly what Burawoy appears to be doing with his distinction between "instrumental" and "reflexive" knowledge, the latter being about ends rather than just means (e.g., Burawoy 2005:11 ff.; 2007:244). It allows him to claim that the values and politics we have decided on among ourselves, after due democratic deliberation, of course, may not be sociologically "valid" in exactly the same sense as, say, social mobility rates or crime statistics are, but they are sociologically valid in the "reflexive" sense. ${ }^{15}$

Now, once again supposing, however unrealistically, that we could form a consensus close enough to unanimity among ourselves on some nontrivial value or political stance to pull something like this off in a vaguely credible manner, what could be gained from that? First, if we insist that the outcomes of our democratic deliberations are a matter of sociological knowledge, albeit of the reflexive type, we are clearly claiming more than simply a place around the public table to discuss values and politics with our fellow citizens. We are invoking our special expertise as sociologists and the authority of sociology as a scientific enterprise. And that authority, such as it is, consists precisely of the claim that what we, qua sociologists, have uncovered about the social world is valid for sociologists and laypersons alike. Stated differently, we are in effect claiming a special expertise, one surpassing that of the ordinary, sociologically uninformed citizen out there, in matters of values and politics. In effect, we are reserving the process of democratic deliberation for ourselves while passing our opinions off to the rest of the public under the authoritative banner of social science, thereby denying or short-circuiting its open, democratic deliberative process. Is that what we mean by "deepening ... democracy"?

Let us not dwell on the chillingly antidemocratic arrogance of this position, familiar though it is from the thinking of many Marxists and ex-Marxists (but see, e.g., Tittle 2004). ${ }^{16}$ Fortunately, sociologists do not occupy important enough social positions for such arrogance to ever become a real threat to democracy anywhere but within the ineffectual confines of various "action committees" gathering at annual conferences of assorted "associations." The more immediate issue is whether passing

15. Some time ago, Burawoy used a similar tactic in trying to rescue Marxism's scientific credentials by arguing that according to Lakatos' modified Popperianism the systematic refutation of a theory's predictions do not necessarily make that theory any less of a scientific theory (Burawoy 1990).

16. It is worth noting that Habermas has had exactly the same difficulties in sorting out the crucial "democracy for whom" question as Burawoy, getting himself entangled in exactly the same contradictions and confusions (see van den Berg 1980; 1990). 
off the values and politics we can agree on as our collective "reflexive knowledge" will do either those values and politics or us collectively any good. We are fairly certain it would not. First of all, it takes a rare combination of intellectual arrogance with a total lack of political realism, not to mention an utter lack of sociological sense, to believe that the "public" is dumb enough not to see right through the ruse of pushing our political preferences as "reflexive knowledge." Second, this being so, all we could possibly accomplish by giving specific values and political positions the stamp of approval of the discipline of sociology is to both discredit those values and positions and ourselves. At the very least, all research conducted by sociologists having anything at all to do with these values and political positions would be automatically disqualified by all nonsociologists, an outcome not very helpful for either the causes or the discipline. Finally, insisting that the values and positions in question represent the only "correct" sociological position possible is an open invitation to those colleagues who happen to disagree to start their own sociologies, complete with separate associations, degrees, etc. Again, not exactly a prospect likely to strengthen the discipline and its reputation. In short, to present our political views as somehow sanctioned by, or the product of, our special expertise as sociologists is a very, very bad idea indeed, morally, politically, practically, and professionally. In conclusion, then, the call for sociologists to constitute themselves into a united lobby for specific values and politics is either pointless or as antidemocratically arrogant as it is silly and self-destructive. ${ }^{17}$

\section{"Public Sociology" in Canada? Some Lessons from the Canadian Sociology of Social Movements}

According to Burawoy, US sociology is unique in the degree to which "professional" (i.e., academic, social-scientific) sociology dominates the other kinds of sociology. In other countries and parts of the world, he maintains, public, policy, and critical sociologies are far more prominent and widely appreciated, although, regrettably, the US model seems to be spreading (Burawoy 2005:20-22). Canada constitutes an interesting comparative case: there has been much alarm about Canadian sociology becoming a mere branch of US sociology (Cormier 2004). It can also be argued that Canadian sociology is quintessentially characterized by the strength of "its critical and left-wing traditions" (McLaughlin 2005:4). From casual observation of the two countries' main sociological journals

17. See Boyns and Fletcher (2007) and Holmwood (2007) for alternative criticisms of this aspect of Burawoy's appeal for more public sociology both concluding that it will inevitably end up marginalizing the discipline rather than strengthening it. 
and conferences, one gets the impression that, in Canada, sociologists of the critical and organic public variety are far better represented than in the US.

Perhaps not surprisingly, engaged organic public sociology is particularly well represented within the Canadian sociology of social movements. One studies the movements one finds most interesting, after all, and many of us would find the movements we ourselves strongly identify with the most interesting of all. This also suggests that examining the subfield of the sociology of social movements might give us some valuable insights into what the beneficial or harmful effects are, in practice, of the presence of organic public sociologists in the field. As we have seen, organic public sociologists constitute a critical element in Burawoy's argument. Consequently, taking a closer look at how the place of organic public sociologists among Canadian sociologists of social movements has affected the quality of their own work, the standing of the discipline and, of course, the fate of humanity, provides us with an excellent opportunity to assess that argument.

The Canadian social movements field is best characterized as a continuum of scholarly approaches. Scholars at one end of the continuum, in what we would call mainstream scholarship, focus on collective protest in support of the full range of public causes, including Aboriginal rights, nationalism, the environment, Canadianization in academia, women, pro- and anti-gay rights, and pro- and anti-abortion rights, to name only a few areas that have received significant attention. This tendency takes its inspiration from what Burawoy would call professional approaches which are often, but by no means always, of American provenance (McCarthy and Zald 2002; 1977; Tarrow 2005; 1998; Tilly 1978; Polletta 2004).

This mainstream approach, applied mostly by sociologists or political scientists in Canada, is largely influenced by questions emerging from the post-1960s American (resource mobilization, political process, transnational contentious politics) and/or European (new social movements) theoretical traditions in the field. Mainstream scholars tend to shy away from engagement with either classical or contemporary theoretical treatments of society, social change, and structure and agency (Marx, Gramsci, Weber, Foucault, Bourdieu), preferring to employ a variety of methodologies and cases in empirical studies identifying the central macro-, meso-, and micro-level mechanisms that account for movement emergence, maintenance, successes, or failures (Wilkes 2006; 2004; Stanbridge 2007; 2005; Kowalchuk 2005; Ramos 2006; Staggenborg and Lang 2007; Cormier 2004; Fetner 2001; Tindall 2002; Smith 1999). In Burawoy's terms, mainstream scholars are concerned with the pro- 
duction of instrumental knowledge based on what they present as dispassionate assessments of the competing models of the ways that various publics are affected by, challenge, and seek to change complex political and cultural relations and power configurations. The explicit aim is the accumulation of knowledge to advance theoretical explanations of social movement dynamics across differing social and political contexts, not advocacy for "humanity" or the forging of close relationships between researchers and the social movements they study.

The latter is one of the stated or implied objectives of Canadian social movements scholarship located at the other, activist-oriented end of the continuum, consisting of a mixture of "organic public" and "critical" sociologists in Burawoy's parlance. ${ }^{18}$ While many of the more activist-oriented scholars in Canadian sociology pay their respects to the intellectual progenitors of mainstream scholarship, the distinguishing characteristic of their work is the coupling of empirical investigation of movement politics and dynamics with varying levels of programmatic commitments to cultivating theoretical and practical insights aimed at supporting subaltern publics in their mobilizations against particular structures or sites of oppression and injustice. Wishing to go beyond the mere identification and assessment of explanatory mechanisms, activist-oriented scholars seek to develop the theoretical insights that they believe will assist and strengthen historical and contemporary instantiations of progressive protest. In their search for a scholarly praxis of social change, the most explicitly activist Canadian scholarship travels between liberal, Marxist, neo-Marxist, Gramscian, postmodern, and, most recently, anarchist theories of the state, (global) civil society, difference, and subjectivity to describe, highlight, and interrogate the social change potentials of the latest manifestations of public resistance at the local, national, and global levels (Smith 2008; Conway 2004; Canel 1992; Magnusson 1992; Ratner 1992; Carroll 1997; Angus 2001; Dhruvarajan 2003; Day 2005). While Canadian scholars on the activist-oriented side of the continuum may disagree over the theoretical terrain (modernist

18. We note that activist-oriented scholarship on social movements in Canada comprises studies investigating the dynamics of social movements as well as those that focus more specifically on the particular causes of oppression that are addressed by campaigns or movements of popular protest. While a more detailed discussion is beyond the scope of this essay, it is interesting to note that some of the scholars of social movements and oppression at the activist-inclined end of the continuum make their institutional homes in cultural studies, humanities, and women's studies departments as much as in sociology and political science. Expanded consideration of these nuances would situate activist-oriented Canadian studies of social movements and oppression in relation to the themes provocatively discussed by Davies in this special edition, and would more carefully explore the distinctions and overlaps between activist-oriented tendencies towards "critical" and "organic public" sociology. 
versus postmodern) best suited to both apprehending and supporting progressive movements (Carroll 1997; Carroll and Ratner 1996a; Day 2005; Mooers and Sears 1992), all strive to produce knowledge of the local and global political-moral issues of the day that is reflexive in its discursive empathy, relevance, and/or practicability for progressive civil society publics and the social justice projects they pursue, thus falling squarely within Burawoy's category of "organic public" sociology.

In terms of the public sociology debate, then, the sociological subfield of social movements in Canada can be understood as comprising two coexisting and partly overlapping trends in scholarship that are best evaluated by conceptually distinguishing research practices from the explicit or implied programmatic statements of particular scholars. That is, while sociologists on both ends of the mainstream-activist-oriented continuum publish studies of social movements that are built upon empirical investigations of cases and contexts of civil society activism, those on the more activist-oriented end distinguish themselves by the prominence they give to programmatic analyses and statements of the "organic" kind favoured by Burawoy. ${ }^{19}$ In short, there is a considerable proportion of Canadian social movements scholars for whom the use of the methods and findings of sociological research to advance theoretical and/or practical support for a particular movement's cause is a primary and legitimate scholarly pursuit. Consequently, we see no sign of any "hegemony" of "professional sociology" in Canada relegating the "organic" approach to the less than respectable fringes. Quite to the contrary, although we do not have the space here to document this in full, at the annual meetings of the Canadian Sociological Association the latter often appear to be the "hegemonic" ones and the former on the margin. ${ }^{20}$ Casual inspection of the Canadian journals, publishing houses, and sessions of other sections of the CSA suggest that this may not be a situation unique to the social movements subfield. So it seems that to some extent we Canadians have been practicing for some time what Prof. Burawoy is preaching. Now, building on our admittedly cursory presentation of certain trends within Canadian social movement scholarship, let us consider to what extent this has brought us and, of course, humanity, the benefits he envisages.

19. While the quality and depth of recent research contributions within mainstream social movement scholarship (see for example, Ramos 2006; Wilkes 2004; 2006) are not dissimilar from many of those produced by some the most committed activist-oriented scholars (see for example, Carroll and Ratner 2001; 1996a; 1996b), the varying scope and nature of scholarly outputs on each end of the continuum suggested here can be better understood by considering the programmatic positions on movement activism alongside which they are presented. This notion will be elaborated upon below.

20. Although a minor renaissance of the mainstream tendency, at least within the social movements section, may currently be underway. For the program of the Association's 43rd annual meeting see http://www.csaa.ca/AnnualMeeting/2008Programme.pdf. 


\section{Canadian Movement Scholars as Organic Public Intellectuals}

What does it mean for sociology in Canada that a major subset of social movement scholars is already active, recognized, and rewarded for approaching their research as "organic sociologists" along the lines advocated by Burawoy? For one thing, it means that the field apparently accommodates widely differing approaches to the knowledge-producing relationships between researchers and their subjects of study. While scholars on the mainstream side of the social movements continuum surely find the publics and political issues they study of great interest and importance, they do not study them in the service of crafting the products of research into tools for those publics, and their supporters, to use in mobilization for social change. And while scholars on the activistoriented side of the continuum may well take the values and methods of social science inquiry seriously, the reality of politically engaged scholarship means that they must grapple with the implications of interpreting and presenting the subaltern publics they study in ways that could undermine their political claims. In short, while mainstream scholarship on social movements in Canada tends to uphold a research program of maintaining critical distance between researcher and activist subjects of study, activist-inclined studies of social movements necessarily tend to disseminate research findings premised on the principled reduction of that distance. In our opinion, two interlinked weaknesses particularly characteristic of the activist-oriented approach to studying and writing about social movements threaten to render the research contributions of organic public intellectuals more harmful to the discipline of sociology in Canada than helpful.

The first major weakness found within the activist-oriented scholarship on social movements in Canada arises from the superficial and incomplete conceptualization of civil society on which it is usually built. Though Burawoy responds to this line of criticism directed against public sociology in general by acknowledging that there lies danger in giving civil society and the public sphere a "purely positive valence" (2004:129), neither he nor any of public sociology's strong defenders moves beyond the refrain that the source of civil society's competitive interests and fissures consists of the colonization and commodification being wrought by states and markets in the first place. State and market forces colonize publics in civil society, making civil society unsafe for publics, so publics, with the help of sociologists, must "study and inveigh" (2004:129) against states and markets. Reiterating one of public sociology's basic presuppositions might suit the immediate purposes of activist-oriented citizens of liberal democracies but it does not address 
the fundamental criticism that public sociologists either conceal or don't want to face what civil society is all about.

Denying an equation between social critique, the fight for justice, and left politics in particular, Burawoy insists that public sociology is not directed at publics oriented towards any single political "valence." But we, and many others (Brint 2007; Brady 2004; Nielsen 2004; SmithLovin 2007; Abbott 2007), have already noted that undemocratic, promarket, antichoice, white supremacist, heterosexist, promilitary interventionist publics, among others, are not really likely to figure on the list of communities that public sociologists would view as being in need of study or support. Yet members of these publics are active in civil society. Some of them are even opposed to the state and the market. Are members of these publics inherently enemies of public sociology or are they simply suffering from false consciousness and in need of vanguard sociologists to help them see the proper way to mobilize in defense of humanity? Public sociology's advocates don't provide satisfactory answers to these uncomfortable questions about the full composition of civil society (Brint 2007:246-8). We see an association between this paucity and additional problems inherent in the activist-oriented approach to the study of social movements in Canadian sociology.

Very simply put, while much of Canadian social movements scholarship focuses on the claims-making mobilizations of left-wing publics in civil society, ${ }^{21}$ activist-oriented works proceed from the implicit public sociology presupposition that only the activism of the groups and communities of the "progressive" left represents the true democratic and social justice interests and aspirations of disenfranchised citizens everywhere. ${ }^{22}$ Leftist publics are not only studied by activist-oriented scholars because they are interesting vis-à-vis theoretical explanations

21. See Carroll (1997:3-8) for a trajectory of some of the earliest examples of Canadian movement scholarship on leftist activism. Beyond activism addressing women's social and political issues (Staggenborg and Lang; Kruzynski 2004; Narushima 2004; Mensah 2000; Gunew 1998; Michaud 1997; Fiske 1996), recent scholarly efforts in Canada focus heavily on progressive mobilization for Aboriginal rights (Wilkes and Ricard 2007; Ramos 2006; Long 1997), queer issues (Fetner and Kush 2008; Smith 1999; Sears 2005; Meyer-Cook and Labelle 2004; Rudy 2001), the environment (Haluza-Delay 2008; Mallory 2006; McCarthy 2006; Harter 2004), and against corporate globalization (Day 2005; Chodkiewicz 2003; McNally 2002). But see Harrison (2008); Harrison et al. (1996); and Harrison and Krahn (1995) for notable exceptions to a strict research emphasis on left protest.

22. In a politically liberal essay, Angus (2001), for example, acknowledges that healthy democracies are constantly emerging from contestation between diverse publics from all sides of the political spectrum over "the best route to sustainable human and natural life" (2001:85). In highlighting, however, the current movements whose public contentions are most likely to usher in the needed reinvigoration of community and democracy, he emphasizes standard movements of the left (2001:41, 80-86). 
of the dynamics of social movements, but also because giving them research attention is part and parcel of theoretical programs that define left movements a priori as the most just social and political causes. ${ }^{23}$ Even if we could share these scholars' supreme confidence in automatically seeing within the life worlds of leftist activist publics the "alternative social visions ... imbued with the potential for a counterhegemony" that are needed for the fight to (re)enact democracy and dignity for all of humanity (Carroll 1997:26-27), we would still insist that, to make their research on the political-moral challenges of the day truly relevant, or reflexive in public sociology's terminology, organic public scholars in Canada must address the composition of (global) civil society with a much broader and realistic focus than they currently do. To further demonstrate this weakness, we can briefly contemplate its implications in relation to the challenge of studying the Israeli-Palestinian conflict, a serious global issue with which one of us has had experience as both advocate and scholar. ${ }^{24}$

As an ongoing political-moral quandary of interest to many Canadian academics and citizens, mobilization for peace and justice in the Israeli-Palestinian conflict is surely the exact type of case of civil society activism that is likely to be of interest to activist-oriented scholars. How exactly could studying mobilization in relation to such a complex political conflict provide theoretical or practical insights contributing towards its just and equitable resolution? Is it entirely clear which one of the publics that are involved in the various civil society battles over IsraelPalestine should be recognized as the leaders of progressive mobilization in pursuit of peace, justice, and democracy? Should organic public intellectuals in Canada gravitate towards studying those activist publics that have vigorously taken up the call to mobilize against Israeli "Apartheid" and to create a single secular democratic republic in Israel-Palestine? What about those who, despite the tremendous contradictions and disappointments of the Oslo and post-Oslo period, advocate a just two-state solution believing that it represents the only realistic resolution to the conflict? Or should Canadian publics convinced that there should never be a Palestinian state be studied and situated in the research programs

23. In a recent example, after advancing a broad conceptualization of the working class in Canada, Camfield (2008) uses an antiracist feminist Marxist theoretical perspective to argue that increased strategic militancy by the labour movement in mobilizing to block the employers' agenda in the workplace and in stopping neoliberalism "matters a great deal to most people in Canada, whether or not they appreciate it" (2008:78-81). Additional examples will be highlighted below.

24. In addition to conducting scholarly research and publishing on peace and human rights activism in Israel-Palestine, Goldberg has led and participated in numerous JewishIsraeli-Arab-Palestinian civil society projects in Canada and the Middle East promoting national co-existence between Israelis and Palestinians. 
of organic public scholars as the true defenders of humanity and global justice? Reflecting public sociology's programmatic proclivity towards conceptualizing leftist and relatively powerless civil society publics as the most authentic holders of humanity's democratic and liberatory potentials, we suspect that a majority of Canada's activist-oriented sociologists would focus their research efforts on those groups and communities comprising the first category of publics. ${ }^{25}$

The point here is that grappling seriously with moral-political challenges demands scholarly openness to understanding the multiplicity of experiences and actors operating within (global) civil society. Assessing the potential benefits that movement activism can bring to those suffering in Palestine and Israel, for example, would mean that scholars not only study the publics they support but also the potentials for these publics' political positions and strategies to be effective in relation to the existence and operations of a range of publics that they dislike. ${ }^{26}$ If, on the basis of either an acknowledged or implied programmatic principle, the majority of activist-oriented scholars in Canada chose to devote their research to only the most leftist Canadian publics mobilized vis-à-vis the conflict, this would not only confirm that organic public sociology restricts itself to a single political-moral vision but, and possibly worse, it would also curtail true reflexivity by foreclosing scholarly openness to the full range of actors and political possibilities revolving around the problem under study. And, conversely, activist-oriented scholars conducting research on all Canadian publics active on the conflict would reveal openness to a truly wide range of political positions among public sociologists in Canada. The resulting research attention given to publics supporting fundamentally irreconcilable political-moral visions for peace and justice in Israel-Palestine would make a mockery of the claim that organic public sociology can help constitute voices in support of some undifferentiated "humanity."

Premised as it is on an incomplete and rosy conceptualization of civil society that highlights left-wing publics as the only ones politically worthy of research, activist-oriented scholarship of social movements in

25. See McLaughlin (2008) for a recent account of the ways that civil society publics addressing Israel-Palestine from both the left and right have been vying for the presence and legitimacy of their causes on university campuses in Canada. McLaughlin also addresses the uneven responses by faculty and university administration officials to such developments.

26. For a remarkably comprehensive analysis of the validity of employing the South African Apartheid model to both critique the Israeli state and to develop practical politicalsocial policy to address the Israeli-Palestinian conflict, see Adam and Moodley (2005). This analysis of conflict resolution in Israel-Palestine, conducted by sociologists based in Canadian universities, is most rare in its effort to assess the justice claims, realities, and possibilities open to the variegated publics and polities in both Israel and Palestine. 
Canada appears to be programmatically inclined to avoid directing questions towards some of the very social realities, dynamics, and complexities that must be weighed by those truly seeking to play a constructive role in relation to the vexing political-moral problems of our times. By replicating an unresolved weakness within public sociology's conception of civil society, activist-oriented movement scholars both limit the potential of the contributions they make to the scholarly reputation of the discipline of sociology in Canada and fail to conduct research that helps to clarify what truly can be done by those wishing to act in the defense of democracy and humanity.

The second set of problems inherent in the activist-oriented approach to the study of social movements in Canada centres on the credibility of scholarship based on programmatic approaches that reduce the distance between researcher and subject. There may be good reasons for bringing sociology to play a greater role in public life through close partnerships between sociologists and grassroots publics, but reducing the distance between researchers and members of the wider society they study can necessitate the privileging of activist-oriented community-building actions (changing society) over the standards and practices of social science (understanding society). This situation is undoubtedly appealing to those who take as axiomatic the connection between fighting for social justice and sociology (Collins 2007; Piven 2007), as well as to those who prefer the lived experience of the "imperfect whole" of the front lines to working through the intellectual implications of theoretical constructs that don't easily relate to actual conditions (Burawoy et al. 2004). It is problematic for those who are uncomfortable with the idea that truth value in research is engendered by a mutually supportive dialogue with publics (McLaughlin et al. 2007; Smith-Lovin 2007). In short, in asking sociologists to address political-moral concerns more directly in their work, supporters of public sociology declare the classical dichotomy between science and advocacy to be both false and dangerous to the fate of humanity. While we accept the charge that scholarly theory can often resemble a "secret language" (Burawoy et al. 2004:111) of scholars more than explanations of the lives of the subjects from which it is derived, we can also briefly show why the narrowing of distance between researchers and subjects in the activist-oriented literature on social movements fails to bring the benefits promised to the discipline of sociology in Canada.

Whereas mainstream Canadian scholars of collective action are content to look at "influential theories in the field, the issues they raise, and how they help to explain ... mobilization and outcomes" (Staggenborg 2008:2), activist-oriented scholars insist on adding programmatic statements of a normative nature promoting or furthering movement protest. 
So, for example, Saul (2005) adds to his solid analysis of the historical dynamics of popular movement activism that contributed to the elimination of apartheid in South Africa by arguing for "the continuing necessity of a revolutionary, even socialist, emancipation in Africa" given the severity of social crises brought on by "international-financial-institutionsponsored 'economic fundamentalism"" that forces African countries "to 'compete' ever more nakedly in a game they cannot possibly win" (2005:257). Or, for example, Dhruvarajan (2003) elucidates classes of negative outcomes of global economic policies on women as well as forms of resistance that they have engendered, but it is clearly just as vital to her that this empirical data instill a "commitment to the cause [that] should inspire us to become activists in transforming this world to become a just and caring place for all" (2003:193). And, lastly, Day's (2005) persuasive demonstration that today's antiglobalization activists prefer local "direct action for the construction of sustainable alternatives" to challenging the state melds seamlessly into a theoretical praxis proposing that "most of our energy ... go into" enacting those strategies best suited to "achieve the goals of revolution and reform here and now, rather than putting them off to some distant place and time" (2005:215). As inspirational as it must be to some, the question is how is the quality of knowledge affected by anchoring research practices to programmatic positions expressing clear strategic affinities between activist-oriented scholars of movement activism and the mobilization projects of the publics that they study?

William Gamson, a highly respected scholar of social movements and proponent of public sociology, acknowledges that the sociologist in an engaged partnership with civil society publics has a responsibility to use "first-rate professional sociology" to provide "tough-minded" assessments that will help those publics to relate to the world as it actually exists and not as it ought to be (Burawoy et al. 2004:108). It is, however, only by failing to really address the implications of the tensions that can arise between such scholars and "their" publics that he can casually couple this commitment to research "objectivity" with a declaration that the dichotomy between science and advocacy is false. What will happen to a public sociologist's findings if, for example, his research partnership is strained because his objectivity about movement strategy has been misunderstood by the publics he works with? Or if it is deliberately disrupted by movement activists because a sociologist's tough-minded assessments have been understood all too well? Ryan, one of Gamson's own colleagues, frankly acknowledges that dialogue between sociologists and their partners in civil society won't always smooth over the disagreements, pressures, and competing interests that inevitably appear (Burawoy et al. 
2004:112), but, like most supporters of public sociology, she fails to see the damage that can be done to both the credibility and the usefulness of scholarly knowledge when researchers find themselves in the position of having to choose between their version of the truth and that which is held by the subjects they study and support (McLaughlin et al. 2007).

Given such a remarkable lack of reflection on these potential tensions it is no surprise that activist-oriented scholars in Canada rarely appear to see, and thus analyze, movement challenges, responses, and action strategies differently from how members of the movements they study view things themselves. ${ }^{27}$ Returning to the Israel-Palestine example to further this point, and in a not-at-all farfetched scenario, what would happen to a sociologist-advocate of Palestinian self-determination conducting research on pro-Palestinian publics in Canada if she were to discover serious inaccuracies in certain of the cherished factual assumptions underpinning her pro-Palestinian public's political stances? Inevitably, such a researcher would face a dilemma that would affect her efforts to contribute knowledge to the field of social movements: either downplay her findings and their possible implications for the movement's practices to maintain the partnership or try to persuade activists of the inaccuracy of their assumptions and its relevance to their struggle with the obvious risk of creating a rift between the academic and "her" public. If, out of a programmatic commitment to use the academy as a means of supporting civil society publics, an activist-oriented scholar were to resolve this potential dilemma by withholding her true assessments of movement strategizing, she would thereby necessarily reduce the validity of her findings. If, on the contrary, she chose to express herself freely in her research findings in order to produce the best scholarship possible she would clearly run the risk of endangering the closeness of her relationship with her comrades.

We are not claiming here that sociologists can study politicized, or any, human subjects in a value vacuum. We do suggest, however, that accepting the argument that distance between science and advocacy is not absolute is not tantamount to insisting that it cannot, or should not, exist in reasonable measure..$^{28}$ Building research projects that are tethered to

27. Illustrating the aversion of activist-oriented scholars in Canada to approaching research subjects with some amount of programmatic distance, we note how Steele and Mathews, both movement observers and participants themselves, responded to Cormier's (2004) scholarly investigation of the Canadianization movement in Canadian academia and culture by decrying our late colleague's work for, among other things, studying activism with neocolonialist "theories" that have "little or no relevance to understanding and solving [a] ... problem in a Canadian context" (2006:502).

28. Greater elaboration is beyond the scope of this essay but, from some personal experience, we disagree with Gamson's casual dismissal of the potential for science-advocacy tensions to disrupt the quality of scholarly efforts and outputs. In his own scholarly 
closed political-theoretical programs ${ }^{29}$ invariably leads activist-oriented scholars of social movements in Canada to produce scholarship that effectively parrots the political perspectives and strategic calls of the publics they study. When activist-oriented scholars present their empirical findings to "fit" with the political positions of their subjects, this automatically renders their knowledge claims one-sided in perspective and thus utterly unlikely to convince anyone but those already convinced of the legitimacy of their claims. But worse still, not only is such scholarship automatically discredited in the eyes of all but the "public" it ostensibly serves, in the end it will inevitably be useless or even damaging to the very cause of the public that is the object of such academic attention. Surely movement activists are ultimately no less ill-served by academic yes men eager to "support" their cause, as kings and statesmen are by the yes men they tend to surround themselves with. As Max Weber famously put it: "The primary task of a useful teacher is to teach his students to recognize 'inconvenient' facts - I mean facts that are inconvenient for their party opinions. And for every party opinion there are facts that are extremely inconvenient, for my own opinion no less than for others" (Weber 1948:147, emphasis added). These words remain as true as ever, especially for those really concerned with the actual impact that mobilizations for social justice, in Canada as elsewhere, could and should have.

A closer look at the prominence and contributions of activist-oriented sociologists among Canadian sociologists of social movements, leaves us neither optimistic about the claim that more public sociology would positively affect the standing of the discipline of sociology in Canada nor about the idea that unleashing the organic public intellectual within would assist in achieving Michael Burawoy's greater goal of establishing an effective sociology-civil society bulwark for humanity. By relying on a narrow conception of civil society that stems from a particular political predisposition, activist-inclined scholars merely reveal that they

engagement with conflict in Israel-Palestine, Goldberg has experienced resistance to efforts to bring practically oriented theoretical modalities to grassroots publics for the purpose of conducting research on civil society social justice projects. In these cases, activists on both sides of the conflict based in Canada were far more closed to dialogue on the strengths and weaknesses of their strategic positions in relation to sociological knowledge than were those in Israel-Palestine. For efforts to study peace and human rights activism in Israel-Palestine that aimed to achieve sufficient researcher-subject distance to openly assess both strengths and weaknesses of local movement activity, see Goldberg (2006; 2008).

29. While much contemporary activist-oriented scholarship continues to be animated by programmatic approaches to political economy that pick up on earlier entreaties declaring the need to "finish the Marxist project rather than abandon it" (Ratner 2002:236), other fashionable bases of activist-oriented scholarship grow out of theoretical engagements with neoliberal globalization (Dhruvarajan 2003) and the environment (McKenzie 2008) that search for new potential emancipatory subjects. 
only truly interested in the fate of leftist publics. Their programmatic commitment to closed theoretical programs that eliminate strategic and ideological distance between researcher and subject only raises concerns about the credibility and utility of knowledge claims of movement activism and politics that are advanced by these public sociologists. In sum, by neither achieving the best promises of social science nor being able to produce knowledge that is actually practically relevant to the people they study, the activist-inclined approach to social movements shows how both the public image and the practical utility of Canadian sociology would only be further undermined if this sort of "public sociology" became even more prominent than it already is.

\section{Conclusion}

In response to Burawoy's call for a "public sociology" and the ensuing debates we have tried to make four major points. First, Burawoy's conception of "public sociology" is, in effect, a hybrid of several different kinds of activities and stances which may or may not be mutually incompatible but which should, in any case, be assessed separately on their respective merits. Second, many of his recommendations for more public activity on behalf of or by sociologists, including better marketing of the discipline, sociologists taking on various civic roles and sociologists acting as public intellectuals, are entirely uncontroversial and/or actively and widely put into practice already. We see no reason to argue against the desirability of any of these nor do we see any reason for extended debates about them. Third, two of his recommendations, the promotion of "organic public sociology" and the conversion of the discipline, or its major association(s), into self-styled players in the political arena are considerably less innocuous. Merely advertising the somewhat left-ofcentre political position of the average sociologist would probably only do minor damage to the standing of the discipline but it would certainly not bring any of the benefits expected by Burawoy. Anything going beyond this, we argue, would be plainly self-destructive and politically and morally highly dubious to boot. Fourth, our brief survey of some trends in Canadian social movements scholarship suggests that, first, there is no sign of any "hegemony" of "professional" sociology to be begin with and, second, that, if anything, this is to be regretted, not celebrated.

Let us end with a brief not-so-academic thought experiment. Suppose that our "critical" and "organic public" colleagues were to succeed in breaking the "hegemony" of the "professional" sociologists on a significant scale, forming the majority, or at least a large minority, in 
most departments in the country. Arguably, this can already be said to be the case in a number of sociology departments in Canada. Now, how would such a more or less successful "coup" against "professional" sociology's dominance within academia affect the discipline as a whole? The long-term outcome is not hard to predict: eventually the discipline would split into an even more fragmented collection of politically engaged but underfunded and not very respected academics who may or may not succeed in keeping the label "sociology" for their own disparate activities, on one side, and some other discipline, call it "social science," which focuses on what Burawoy calls "professional sociology," builds a reputation for scientific solidity and rakes in all the research dollars, positions, and awards, on the other. It is not a future we anticipate with great pleasure. ${ }^{30}$

But then again maybe all this is just a tempest in a teapot. After all, while confusingly arguing for the rehabilitation of public sociology, Burawoy also repeatedly argues that professional sociology is necessarily the primus inter (not so) pares among the four different kinds of sociology:

There can be neither public nor policy sociology, however, without a professional sociology that develops a body of theoretical knowledge and empirical findings, put to the test of peer review. Professional sociology provides the ammunition, the expertise, the knowledge, the insight, and the legitimacy for sociologists to present themselves to publics or to powers. Professional sociology is the sine qua non of all sociologies ... the fact is that today without professional sociology there can be no other sociology.

Amen and let's try to keep it that way.

\section{REFERENCES}

Abbot, Andrew. 2007. For humanist sociology. Pp. 195-212 in Dan Clawson, Robert Zussman, Joya Misra, Naomi Gerstel, Randall Stokes, Douglas L. Anderton, and Michael Burawoy, eds., Public Sociology: Fifteen Eminent Sociologists Debate Politics and the Profession in the Twenty-First Century. Berkeley, CA: University of California Press.

Adam, Heribert and Kogila Moodley. 2005. Seeking Mandela Peacemaking Between Israelis and Palestinians. Philadelphia: Temple University Press.

30. Jonathan Turner actually looks forward to such a split between the two types of sociology (see Turner 2007:276ff.). We are not so sure but this is not the place to debate the question. 
Angus, Ian. 2001. Emergent Publics An Essay on Social Movements and Democracy. Winnipeg: Arbeiter Ring Publishing.

Bonacich, Edna. 2007. Working with the labor movement: A personal journey in organic public sociology. Pp. 73-94 in Lawrence Nichols, ed., Public Sociology: The Contemporary Debate. New Brunswick, NJ: Transaction Publishers.

Boyns, David and Jesse Fletcher. 2007. Reflections on public sociology: Public relations, disciplinary identity, and the strong program in professional sociology. Pp. 119-148 in Lawrence Nichols, ed., Public Sociology: The Contemporary Debate. New Brunswick, NJ: Transaction Publishers.

Brady, David. 2004. Why public sociology may fail. Social Forces 82:16291638.

Brint, Steven. 2007. Guide for the perplexed: On Michael Burawoy's "public sociology." Pp. 237-262 in Lawrence Nichols, ed., Public Sociology: The Contemporary Debate. New Brunswick, NJ: Transaction Publishers.

Burawoy, Michael. 1990. Marxism as science: Historical challenges and theoretical growth. American Sociological Review 55:775-793.

2004. Public sociologies: Contradictions, dilemmas, and possibilities. Social Forces 82:1603-1618.

2005. 2004 Presidential Address: For public sociology. American Sociological Review 70:4-28.

2007. The field of sociology: Its power and promise. Pp. 241-258 in Dan Clawson, Robert Zussman, Joya Misra, Naomi Gerstel, Randall Stokes, Douglas L. Anderton, and Michael Burawoy eds., Public Sociology: Fifteen Eminent Sociologists Debate Politics and the Profession in the Twenty-First Century. Berkeley, CA: University of California Press.

Burawoy, Michael, William Gamson, Charlotte Ryan, Stephen Pfohl, Diane Vaughan, Charles Derber, and Juliet Schor. 2004. Public sociologies: A symposium from Boston College. Social Problems 51:103-130.

Camfield, David. 2008. The working-class movement in Canada: An overview. Pp. 61-83 in Miriam Smith, ed., Group Politics and Social Movements in Canada. Toronto: Broadview Press.

Canel, Eduardo. 1992. New social movement theory and resource mobilization: The need for integration. Pp. 22-51 in William K. Carroll, ed., Organizing Dissent Contemporary Social Movements in Theory and Practice. Toronto: Garamond Press.

Carroll, William K. 1997. Social movements and counterhegemony: Canadian contexts and social theories. Pp. 3-38 in William K. Carroll, ed., Organizing Dissent Contemporary Social Movements in Theory and Practice. Toronto: Garamond Press.

Carroll, William K. and Robert S. Ratner. 1996a. Master frames and counterhegemony: Political sensibilities in contemporary social movements. $\mathrm{Ca}$ nadian Review of Sociology and Anthropology 33(4):407-435. 
1996b. Master framing and cross-movement networking in contemporary social movements. The Sociological Quarterly 37(4):601-625.

2001. Sustaining oppositional cultures in 'post-socialist' times: A comparative study of three social movement organizations. Sociology 35(3):605-629.

Chodkiewicz, Jean-Luc. 2003. Two faces of globalization in Mexico: Maquiladoras and Zapatistas. Pp. 161-178 in Yildiz Atasoy and William K. Carroll, eds., Global Shaping And Its Alternatives. Bloomfield, CT: Kumarian Press.

Cohen, Patricia. 2008. The ' 60 s begin to fade as liberal professors retire. in New York Times.

Collini, Stefan. 2006. Absent Minds: Intellectuals in Britain. Oxford, New York: Oxford University Press.

Collins, Patricia Hill. 2007. Going public: Doing the sociology that had no name. Pp. 101-113 in Dan Clawson, Robert Zussman, Joya Misra, Naomi Gerstel, Randall Stokes, Douglas L. Anderton, and Michael Burawoy eds., Public Sociology: Fifteen Eminent Sociologists Debate Politics and the Profession in the Twenty-First Century. Berkeley, CA: University of California Press.

Conway, Janet M. 2004. Identity, Place, Knowledge: Social Movements Contesting Globalization. Black Point, NS: Fernwood Publishing.

Cormier, Jeffrey. 2004. The Canadianization Movement: Emergence, Survival, and Success. Toronto, Buffalo: University of Toronto Press.

Day, Richard J.F. 2005. Gramsci Is Dead: Anarchist Currents in the Newest Social Movements. Toronto: Between the Lines.

Dhruvarajan, Vanaja. 2003. Feminism and resistance to globalization of capitalism. Pp. 179-194 in Yildiz Atasoy and William K. Carroll, eds., Global Shaping And Its Alternatives. Bloomfield, CT: Kumarian Press.

Esping-Andersen, Gøsta. 1985. Politics against Markets: The Social Democratic Road to Power. Princeton, NJ: Princeton University Press. 2002. Why We Need a New Welfare State. New York: Oxford University Press.

Evans, Peter B., Dietrich Rueschemeyer, and Evelyne Huber. 1985. States versus Markets in the World-system. Beverly Hills, CA: Sage Publications.

Fetner, Tina. 2001. Working Anita Bryant: The impact of Christian anti-gay activism on lesbian and gay movement claims. Social Problems 48(3):411428.

Fetner, Tina and Kristin Kush. 2008. Gay-straight alliances in high schools: Social predictors of early adoption. Youth \& Society 40(1):114-130.

Fiske, Jo-Anne. 1996. The womb is to the nation as the heart is to the body: Ethnopolitical discourses of the Canadian indigenous women's movement. Studies in Political Economy 51:65-95. 
Gans, Herbert J. 1989. 1988 Presidential Address: Sociology in America: The discipline and the public. American Sociological Review 54:1-16.

Goldberg, Avi. 2006. Confronting the absent-present: Material and discursive power in Israeli-Palestinian alliances. Berkeley Journal of Sociology: A Critical Review 50:3-36.

2008. The (meso) politics of externalization: Insider-outsider encounter in transnational contention for Israel-Palestine. Unpublished paper.

Gross, Neil and Solon Simmons. 2007. The social and political views of American professors. Pp. 76: Harvard University.

Gunew, Sneja. 1998. The dilemmas of a multicultural nomad caught up in (post) colonialism. Postcolonial Studies 1(3):321-331.

Halliday, Terence C. and Morris Janowitz. 1992. Sociology and its Publics: The Forms and Fates of Disciplinary Organization. Chicago: University of Chicago Press.

Haluza-Delay, Randolph. 2008. A theory of practice for social movements: Environmentalism and ecological habitus. Mobilization: The International Quarterly 13(2):205-218.

Harrison, Trevor, Bill Johnston, and Harvey Krahn. 1996. Special interests and/ or new right economics? The ideological bases of Reform Party support in Alberta in the 1993 federal election. The Canadian Review of Sociology and Anthropology 33(2):159-179.

Harrison, Trevor and Harvey Krahn. 1995. Populism and the rise of the Reform Party in Canada. The Canadian Review of Sociology and Anthropology 32(2)127-150.

Harrison, Trevor. 2008. Populist and conservative Christian evangelical movements: A comparison of Canada and the United States. Pp. 203-224 in Miriam Smith,ed., Group Politics and Social Movements in Canada. Toronto: Broadview Press.

Harter, John-Henry. 2004. Environmental justice for whom? Class, new social movements, and the environment: A case study of Greenpeace Canada, 1971-2000. (54):83-119.

Hays, Sharon. 2007. Stalled at the altar? Conflict, hierarchy, and compartmentalization in Burawoy's public sociology. Pp. 79-90 in Dan Clawson, Robert Zussman, Joya Misra, Naomi Gerstel, Randall Stokes, Douglas L. Anderton, and Michael Burawoy, eds., Public Sociology: Fifteen Eminent Sociologists Debate Politics and the Profession in the Twenty-First Century. Berkeley, CA: University of California Press.

Holmwood, John. 2007. Sociology as public discourse and professional practice: A critique of Michael Burawoy. Sociological Theory 25:46-66.

Korpi, Walter. 1983. The Democratic Class Struggle. London, Boston: Routledge \& Kegan Paul. 
Kowalchuk, Lisa. 2005. The discourse of demobilization: Shifts in activist priorities and the framing of political opportunities in a peasant land struggle. The Sociological Quarterly 46:237-261.

Kruzynski, Anna. 2004. From operation SalAMI to nemesis: The journey of a group of women in the Quebec "anti-globalization" movement. 17(2):227-262.

Long, David Alan. 1997. The precarious pursuit of justice: Counterhegemony in the Lubicon First Nation coalition. Pp. 151-170 in William K. Carroll, ed., Organizing Dissent Contemporary Social Movements in Theory and Practice. Toronto: Garamond Press.

Magnusson, Warren. 1992. Decentring the state, or looking for politics. Pp. 6980 in William K. Carroll, ed., Organizing Dissent Contemporary Social Movements in Theory and Practice. Toronto: Garamond Press.

Mallory, Chaone. 2006. Ecofeminism and forest defense in Cascadia: Gender, theory and radical activism. Capitalism, Nature, Socialism 17(1):32-49.

Massey, Douglas. 2007. The strength of weak politics. Pp. 145-157 in Dan Clawson, Robert Zussman, Joya Misra, Naomi Gerstel, Randall Stokes, Douglas L. Anderton, and Michael Burawoy, eds., Public Sociology: Fifteen Eminent Sociologists Debate Politics and the Profession in the Twenty-First Century. Berkeley, CA: University of California Press.

McCarthy, James. 2006. Neoliberalism and the politics of alternatives: Community forestry in British Columbia and the United States. Annals of the Association of American Geographers 96(1):84-104.

McCarthy, John D. and Mayer N. Zald. 1977. Resource mobilization and social movements: A partial theory. American Journal of Sociology 82:121241.

2002. The enduring vitality of the resource mobilization theory of social movements. Pp. 533-565 in Handbook of Sociological Theory, edited by Jonathan H. Turner, New York: Kluwer Academic/Plenum Publishers.

McKenzie, Judith I. 2008. The environmental movement in Canada: Retreat or resurgence? Pp. 279-306. in Miriam Smith, ed., Group Politics and Social Movements in Canada. Toronto: Broadview Press.

McLaughlin, Neil. 2005. Canada's impossible science: Historical and institutional origins of the coming crisis in Anglo-Canadian Sociology. Canadian Journal of Sociology 30:1-40.

2008. McMaster University: A comedy of errors over anti-Israeli protests. CAUT Bulletin 55(4) April.

McLaughlin, Neil, Lisa Kowalchuk, and Kerry Turcotte. 2007. Why sociology does not need to be saved: Analytic reflections on public sociology. Pp. 289-315 in Lawrence Nichols, ed., Public Sociology: The Contemporary Debate. New Brunswick, NJ: Transaction Publishers.

McNally, David. 2002. Another World is Possible: Globalization and Anti-capitalism. Winnipeg, MB: Arbeiter Ring Publishing. 
Mensah, Maria N. 2000. HIV-positive women infiltrating the media: Activist visibility and abstraction. Recherches Feministes 13(2):95-112.

Meyer-Cook, Fiona and Diane Labelle. 2004. Namaji: Two-spirit organizing in Montreal, Canada. Journal of Gay \& Lesbian Social Services 16(1):2951.

Michaud, Jacinthe. 1997. On counterhegemonic formation in the women's movement and the difficult integration of collective identities. Pp. 197-212 in William K. Carroll, ed., Organizing Dissent Contemporary Social Movements in Theory and Practice. Toronto: Garamond Press.

Mooers, Colin and Alan Sears. 1992. The 'new social movements' and the withering away of state theory. Pp. 52-68 in William K. Carroll, ed., Organizing Dissent Contemporary Social Movements in Theory and Practice. Toronto: Garamond Press.

Nielsen, François. 2004. The vacant "we": Remarks on public sociology. Social Forces 82:1619-1627.

Narushima, Miya. 2004. A gaggle of raging grannies: The empowerment of older Canadian women through social activism. International Journal of Lifelong Education 23(1):23-42.

Piven, Frances Fox. 2007. From public sociology to politicized sociologist. Pp. 158-166 in Dan Clawson, Robert Zussman, Joya Misra, Naomi Gerstel, Randall Stokes, Douglas L. Anderton, and Michael Burawoy, eds., Public Sociology: Fifteen Eminent Sociologists Debate Politics and the Profession in the Twenty-First Century. Berkeley, CA: University of California Press.

Polletta, Francesca. 2004. Freedom is an Endless Meeting: Democracy in American Social Movements. Chicago: The University of Chicago Press.

Putney, Norella M., Dawn E. Alley, and Vern L. Bengtson. 2007. Social gerontology as public sociology in action. Pp. 95-118 in Lawrence Nichols, ed., Public Sociology: The Contemporary Debate. New Brunswick, NJ: Transaction Publishers.

Ramos, Howard. 2006. What causes Canadian aboriginal protest? Examining resources, opportunities and identity, 1951-2000. Canadian Journal of Sociology 31(2):211-234.

Ratner, R.S. 2002. New movements, new theory, new possibilities? Reflections on counter-hegemony today. Pp. 234-242 in William K. Carroll, ed., Organizing Dissent Contemporary Social Movements in Theory and Practice. Toronto: Garamond Press.

1997. Many Davids, one Goliath. Pp. 271-286 in William K. Carroll, ed., Organizing Dissent Contemporary Social Movements in Theory and Practice. Toronto: Garamond Press.

Rudy, Kathy. 2001. Radical feminism, lesbian separatism, and queer theory. Feminist Studies 27(1):191-222. 
Saul, John S. 2005. The Next Liberation Struggle: Capitalism, Socialism, and Democracy in Southern Africa. Toronto: Between The Lines.

Sears, Alan. 2005. Queer anti-capitalism: What's left of lesbian and gay liberation? Science \& Society 69(1):92-112.

Smith, Miriam. 1999. Lesbian and Gay Rights in Canada: Social Movements and Equality-Seeking, 1971-1995. Toronto: University of Toronto Press. ed. 2008. Group Politics and Social Movements in Canada. Toronto: Broadview Press.

Smith-Lovin, Lynn. 2007. Do we need a public sociology? It depends on what you mean by sociology. Pp. 124-134 in Dan Clawson, Robert Zussman, Joya Misra, Naomi Gerstel, Randall Stokes, Douglas L. Anderton, and Michael Burawoy, eds., Public Sociology: Fifteen Eminent Sociologists Debate Politics and the Profession in the Twenty-First Century. Berkeley, CA: University of California Press.

Stacey, Judith. 2007. If I were the goddess of sociological things. Pp. 91-100 in Dan Clawson, Robert Zussman, Joya Misra, Naomi Gerstel, Randall Stokes, Douglas L. Anderton, and Michael Burawoy, eds., Public Sociology: Fifteen Eminent Sociologists Debate Politics and the Profession in the Twenty-First Century. Berkeley, CA: University of California Press.

Staggenborg, Suzanne. 2008. Social Movements. Don Mills, ON: Oxford University Press.

Staggenborg, Suzanne and Amy Lang. 2007. Culture and ritual in the Montreal women's movement. Social Movement Studies 6(2):177-194.

Stanbridge, Karen. 2005. Nationalism, international factors and the 'Irish question' in the era of the First World War. Nations and Nationalism 11(1):21-42. 2007. Framing children in the Newfoundland confederation debate, 1948. Canadian Journal of Sociology 32(2):177-201.

Stephens, John D. 1980. The Transition from Capitalism to Socialism. Atlantic Highlands, NJ: Humanities Press.

Steele, James and Robin Mathews. 2006. Canadianization revisited: A comment on Cormier's "The Canadianization movement in context." Canadian Journal of Sociology 31(4):491-508.

Tarrow, Sidney. 1998. Power in Movement Social Movements and Contentious Politics $2^{\text {nd }}$ Edition. Cambridge: Cambridge University Press. 2005. The New Transnational Activism. New York: Cambridge University Press.

Tilly, Charles. 1978. From Mobilization to Revolution. New York: Random House.

Tindall, David B. 2002. Social networks, identification and participation in an environmental movement: Low-medium cost activism within the British Columbia Wilderness Preservation Movement. Canadian Review of Sociology \& Anthropology 39(4):413-452. 
Tittle, Charles R. 2004. The arrogance of public sociology. Social Forces 82:1639-1643.

Turner, Jonathan H. 2007. Is public sociology such a good idea? Pp. 263-288 in Lawrence Nichols, ed., Public Sociology: The Contemporary Debate. New Brunswick, NJ: Transaction Publishers.

van den Berg, Axel. 1980. Critical theory: Is there still hope? American Journal of Sociology 86:449-478.

1990. Habermas and modernity: A critique of the theory of communicative action. Current Perspectives in Social Theory 10:161-193. 2003a. The Immanent Utopia: From Marxism on the State to the State of Marxism. New Brunswick, NJ: Transaction Publishers. 2003b. Politics versus markets: A note on the uses of double standards. Pp. 139-152 in Raymond Breton and Jeffrey Reitz, eds., Globalization and Society: Processes of Differentiation Examined. Westport CT: Praeger.

2004. Public choice, the public sector and the market: The sound of one hand clapping? Pp. 13-25 in Pauline Dibben, Geoffrey Wood, and Ian Roper, eds., Contesting Public Sector Reforms: Critical Perspectives; International Debates. Houndmills, Basingstoke: Palgrave.

Weber, Max. 1948. Science as a vocation. Pp. 129-158 in H.H. Gerth and C. Wright Mills, eds., From Max Weber: Essays in Sociology. London: Routledge and Kegan Paul.

Wilkes, Rima. 2004. First Nations politics: Deprivation, resources, and participation in collective action. Sociological Inquiry 74(4):570-589.

2006. The protest actions of indigenous peoples: A Canadian-U.S. comparison of social movement emergence. American Behavioral Scientist 50(4):510-535.

Wilkes, Rima and Danielle Ricard. 2007. How does newspaper coverage of collective action vary? Protest by Indigenous People in Canada. The Social Science Journal 44:231-251.

Wilson, William Julius. 2007. Speaking to publics. Pp. 117-123 in Dan Clawson, Robert Zussman, Joya Misra, Naomi Gerstel, Randall Stokes, Douglas L. Anderton, and Michael Burawoy, eds., Public Sociology: Fifteen Eminent Sociologists Debate Politics and the Profession in the Twenty-First Century. Berkeley, CA: University of California Press.

Avi Goldberg teaches sociology at Vanier College in Montreal. His research and teaching interests include political sociology, social movements and social change, sociological theory, and the relationship between popular culture, new information technologies, and political-economic subjectivities. His publications include: "Confronting the Absent-Present: Material and Discursive Power in Israeli-Palestinian Political Alliances" in Berkeley Journal of Sociology: A Critical Review. Volume 50, 2006, pp. 3-36; "Jewish Communities in Canada: Contemporary Jewish Affairs," (with Morton Weinfeld) in M. Avrum Ehrlich, ed., Encyclopedia of the Jewish Diaspora, ABC-CLIO, USA, 2008; "Educating for Peace in Israel and Palestine: A Transformational Imperative" in Cantilevers, 
Winter, 2000, Volume 7, pp. 28-30. He is currently revising an article and working on a book manuscript on global civil society and Israeli-Palestinian peace and human rights activism during the Oslo peace process.

Axel van den Berg is Professor of Sociology at McGill University. His research interests include labour markets and labour market policy, sociological theory and the relation between economics and sociology. His publications include: The Immanent Utopia: From Marxism on the State to the State of Marxism. Princeton, N.J.: Princeton University Press, 1988 (republished, with a new introduction, by Transaction Publishers, Brunswick, NJ, 2003); Labour market Regimes and Patterns of Flexibility: A Sweden-Canada Comparison, Lund: Arkiv, 1997 (with Bengt Furåker and Leif Johansson); Managing Social Risks through Transitional Labour Markets: Towards an enriched European Employment Strategy, Amsterdam: Het Spinhuis/Transaction Publishers, 2006 (with Erik de Gier); The Social Sciences and Rationality: Promise, Limits and Problems, New Brunswick, NJ: Transaction, 2004 (ed. with Hudson Meadwell); "Is Sociological Theory Too Grand for Social Mechanisms?" in Peter Hedström and Richard Swedberg, eds., Social Mechanisms: An Analytical Approach to Social Theory, Cambridge: Cambridge University Press, 1998, pp. 204-237. 